\title{
REPRODUCTION IN THE UGANDA DEFASSA WATERBUCK, KOBUS DEFASSA UGANDAE NEUMANN
}

\author{
G. A. SPINAGE* \\ Nuffield Unit of Tropical Animal Ecology, \\ Queen Elizabeth Park, Uganda \\ (Received 16th April 1968, revised 10th June 1968)
}

\begin{abstract}
Summary. The reproductive organs of the defassa waterbuck are similar to those of Caprinae. There appeared to be a seasonal fluctuation in testes weight, the lowest weight occurring in the driest month of the year. The female is poly-oestrous and monotocous and can conceive at the first post partum oestrus. Ninety-two per cent of implantations occurred in the right uterine horn but the left ovary was more active than the right. The highest incidence of births appeared to be correlated with the two wet seasons. The lowest incidence of conceptions appeared to be correlated with the lowest maximum temperatures. The possible relevance of temperature to sexual periodicity is discussed.
\end{abstract}

\section{INTRODUGTION}

There is little information on reproduction in the waterbuck, Kobus sp., other than Heape's observation (1901) on the length of di-oestrus in $K$. ellipsiprymnus, Gerhardt's (1933) description of the penis and Amoroso, Kellas \& Harrison Matthew's (1954) investigation of placentation in $K$. defassa. There have been several comments on times of calving in different parts of the continent, and Kiley-Worthington (1965) and Spinage (1968) have described reproductive behaviour.

The present observations were made on the Uganda defassa waterbuck, Kobus defassa ugandae Neumann, in the Queen Elizabeth Park in western Uganda, which is situated between longitudes $29^{\circ} 45^{\prime} \mathrm{E}$ and $30^{\circ} 15^{\prime} \mathrm{E}$, and latitudes $30^{\prime} \mathrm{S}$ and $15^{\prime} \mathrm{N}$. The climate is semi-arid with an average rainfall at Mweya, the Park headquarters, of $670 \mathrm{~mm}$ (26.4 in.) per annum, with dry periods from December to February and June to July.

\section{MATERIALS AND METHODS}

Between August 1963 and April 1967, fifty-nine males and eighty-two females were killed and the reproductive organs obtained. The ages of the animals were determined by the methods outlined by Spinage (1967).

Large organs and foetuses were weighed in the field. Small foetuses were fixed in $10 \%$ formalin and weighed in the laboratory. Pieces of testis and

* Present address: c/o British High Commission, P.O. Box 7070, Kampala, Uganda. 
epididymis were fixed in Susa fluid, and pieces of seminal vesicle and mammary gland in $10 \%$ formalin. Ovaries were fixed in $10 \%$ formalin and afterwards sliced transversely with a razor blade into approximately 1-mm sections. The number of follicles visible to the naked eye was counted and diameters of corpora lutea and follicles of about $5 \mathrm{~mm}$ or more were measured with calipers. Corpora albicantia were counted.

Histological sections were cut at 5 to $8 \mu$. Testes and epididymides were stained in Heidenhain's iron haematoxylin alone, and all other tissues were counterstained with eosin using standard procedures.

Ova were recovered by sectioning the Fallopian tube.

Some animals were captured by using immobilizing drugs (Short \& Spinage, $1967)$ and were released after recovery.

\section{RESULTS}

\section{THE MALE}

General description of the adult reproductive organs

The adult testes had a mean combined weight of $147.9 \pm 4.5 \mathrm{~g}$, and the epididymides had a mean combined weight of $37 \cdot 3 \pm 6.0 \mathrm{~g}$. Adult testis weight was reached in the 5th to 6 th year and did not appear to decline thereafter (Table 1). The seminal vesicles were lobulated and had a mean weight of $21 \mathrm{~g}$. The ampullae of the vasa deferentia weighed approximately $7 \mathrm{~g}$.

TABLE 1

MEAN PAIRED WEIGHTS OF TESTES, EPIDIDYMIDES, SEMINAL VESIGLES AND AMPULLAE OF THE VASA DEFERENTIA FOR EAGH YEAR OF AGE

\begin{tabular}{|c|c|c|c|c|c|c|}
\hline$\underset{\text { (years) }}{\text { Age }}$ & $\begin{array}{c}\text { Sample } \\
\text { size }\end{array}$ & $\begin{array}{c}\text { Mean paired } \\
\text { wt of testes } \\
(\mathrm{g})\end{array}$ & $\begin{array}{c}\text { Mean paired wt } \\
\text { of epididymides } \\
(\mathrm{g})\end{array}$ & $\begin{array}{c}\text { Sample } \\
\text { size }\end{array}$ & $\begin{array}{c}\text { Mean paired } \\
\text { wt of seminal } \\
\text { vesicles }(g)\end{array}$ & $\begin{array}{l}\text { Mean paired } \\
\text { wt of } \\
\text { ampullae }(\mathrm{g})\end{array}$ \\
\hline $\begin{array}{r}1 \\
2 \\
3 \\
4 \\
5 \\
6 \\
7 \\
8 \\
9 \\
10 \\
11\end{array}$ & $\begin{array}{r}8 \\
6 \\
4 \\
2 \\
10 \\
7 \\
8 \\
4 \\
3 \\
5 \\
2\end{array}$ & $\begin{array}{r}4 \\
38 \\
108 \\
68 \\
127 \\
143 \\
151 \\
148 \\
155 \\
151 \\
138\end{array}$ & $\begin{array}{r}2 \\
19 \\
13 \\
14 \\
23 \\
24 \\
42 \\
51 \\
22 \\
27 \\
52\end{array}$ & $\begin{array}{l}1 \\
- \\
- \\
2 \\
1 \\
3 \\
3 \\
1 \\
3 \\
-\end{array}$ & $\begin{array}{l}1.4 \\
- \\
\overline{15.4} \\
20.9 \\
25.7 \\
21.2 \\
18 \cdot 1 \\
18.3 \\
-\end{array}$ & \begin{tabular}{c}
$0 \cdot 7$ \\
\multicolumn{1}{c}{-} \\
- \\
$4 \cdot 7$ \\
$10 \cdot 2$ \\
$5 \cdot 1$ \\
$6 \cdot 4$ \\
$6 \cdot 2$ \\
$7 \cdot 1$ \\
-
\end{tabular} \\
\hline
\end{tabular}

The penis was of the fibro-elastic type similar to that of the ram. The glans was pigmented and bore the urethral orifice at the extremity of a urethral process; this process was extended in the erect penis. The preputial opening was situated about $25 \mathrm{~cm}$ anterior to the testes and the extended penis would probably reach about $15 \mathrm{~cm}$ beyond this point. 


\section{Histology of the testis and epididymis}

The foetal testis had descended to the scrotal entrance by the 111th day of gestation, where it remained until after birth. The germinal cells in a 179-day foetus were similar in size to those found in a male in which spermatogenesis had not commenced, but the foetal gonad contained more interstitial tissue. The development of the testis is summarized in Table 2. All adult testes showed active spermatogenesis without any apparent decline in testis tubule diameter

TABLE 2

DEVELOPMENT OF THE TESTIS

\begin{tabular}{|c|c|c|c|c|}
\hline Age & $\begin{array}{l}\text { Sample } \\
\text { size }\end{array}$ & $\begin{array}{l}\text { Histological appearance } \\
\text { of the testis }\end{array}$ & $\begin{array}{l}\text { Mean diameter } \\
\text { of seminiferous } \\
\text { tubules }(\mu)\end{array}$ & $\begin{array}{c}\text { Appearance of } \\
\text { epididymis }\end{array}$ \\
\hline $\begin{array}{l}\text { 179-day } \\
\text { foetus } \\
\frac{1}{2} \mathrm{yr}\end{array}$ & $\begin{array}{l}1 \\
2\end{array}$ & $\begin{array}{l}\text { Seminiferous tubules without lumina } \\
\text { Tubules without lumina, primary } \\
\text { spermatocytes in division }\end{array}$ & $\begin{array}{l}50 \\
40\end{array}$ & $\begin{array}{l}\text { No contents } \\
\text { No contents }\end{array}$ \\
\hline $1 \mathrm{yr}$ & 5 & $\begin{array}{l}\text { Some tubules with lumina, some } \\
\text { spermatozoa present }\end{array}$ & 50 & No contents \\
\hline $1 \frac{1}{2} \mathrm{yr}$ & 3 & $\begin{array}{l}\text { Many tubules with lumina, sperma- } \\
\text { tids present, spermatozoa rare }\end{array}$ & 110 & $\begin{array}{l}\text { Few spermatozoa and } \\
\text { debris }\end{array}$ \\
\hline $2 \mathrm{yr}$ & 2 & $\begin{array}{l}\text { Many tubules with lumina, few } \\
\text { spermatozoa }\end{array}$ & 110 & No contents \\
\hline $\begin{array}{l}3 \mathrm{yr} \\
4 \mathrm{yr} \\
5 \mathrm{yr} \\
6 \mathrm{yr} \\
7 \mathrm{yr} \\
8 \mathrm{yr} \\
9 \mathrm{yr} \\
10 \mathrm{yr} \\
11 \mathrm{yr}\end{array}$ & $\begin{array}{l}4 \\
2 \\
5 \\
4 \\
6 \\
1 \\
1 \\
3 \\
1\end{array}$ & $\begin{array}{l}\text { Most lumina with spermatozoa } \\
\text { Active spermatogenesis in all tubules } \\
\text { Active spermatogenesis in all tubules } \\
\text { Active spermatogenesis in all tubules } \\
\text { Active spermatogenesis in all tubules } \\
\text { Active spermatogenesis in all tubules } \\
\text { Active spermatogenesis in all tubules } \\
\text { Active spermatogenesis in all tubules } \\
\text { Active spermatogenesis in all tubules }\end{array}$ & $\begin{array}{l}160 \\
160 \\
170 \\
190 \\
190 \\
160 \\
180 \\
180 \\
180\end{array}$ & $\begin{array}{l}\text { Packed with spermatozoa } \\
\text { Packed with spermatozoa } \\
\text { Packed with spermatozoa } \\
\text { Packed with spermatozoa } \\
\text { Packed with spermatozoa } \\
\text { Packed with spermatozoa } \\
\text { Packed with spermatozoa } \\
\text { Packed with spermatozoa } \\
\text { Packed with spermatozoa }\end{array}$ \\
\hline
\end{tabular}

TABLE 3

MONTHLY GONDITION OF TESTES IN ADULTS 6 YEARS OF AGE AND OLDER

\begin{tabular}{|c|c|c|c|c|}
\hline Month & $\begin{array}{l}\text { Sample } \\
\text { size }\end{array}$ & $\begin{array}{c}\text { Mean paired wt } \\
\text { of testes }(\mathrm{g})\end{array}$ & $\begin{array}{c}\text { Mean paired wt } \\
\text { of epididymides } \\
(\mathrm{g})\end{array}$ & $\begin{array}{c}\text { Mean seminiferous } \\
\text { tubule diameter } \\
(\mu)\end{array}$ \\
\hline $\begin{array}{l}\text { January } \\
\text { February } \\
\text { March } \\
\text { April } \\
\text { May } \\
\text { June } \\
\text { July } \\
\text { August } \\
\text { September } \\
\text { October } \\
\text { November } \\
\text { December }\end{array}$ & $\begin{array}{l}3 \\
4 \\
3 \\
3 \\
0 \\
3 \\
6 \\
7 \\
3 \\
2 \\
2 \\
2\end{array}$ & $\begin{array}{c}166 \cdot 7 \\
152 \cdot 5 \\
156 \cdot 7 \\
162 \cdot 3 \\
\overline{138 \cdot 3} \\
117 \cdot 4 \\
136 \cdot 8 \\
126 \cdot 0 \\
155 \cdot 0 \\
160 \cdot 0 \\
155 \cdot 0\end{array}$ & $\begin{array}{l}26 \cdot 6 \\
77 \cdot 5 \\
63 \cdot 3 \\
27 \cdot 7 \\
-\overline{31 \cdot 0} \\
25 \cdot 9 \\
14 \cdot 8 \\
25 \cdot 7 \\
35 \cdot 0 \\
25 \cdot 0 \\
60 \cdot 0\end{array}$ & $\begin{array}{l}215(2) \\
197 \\
174(1) \\
206(2) \\
-169(1) \\
186(3) \\
178(2) \\
180 \\
197 \\
167 \\
193(1)\end{array}$ \\
\hline \multicolumn{2}{|c|}{ Mean \pm S.E. } & $147 \cdot 9 \pm 4.5$ & $37 \cdot 3 \pm 6 \cdot 0$ & $187 \cdot 5 \pm 4 \cdot 7$ \\
\hline
\end{tabular}

Figures in parentheses after last column refer to sample size where this differs from column 2 . 
or testis weight with age. Spermatozoa were first observed in the testis at 1 year and in the epididymis at $1 \frac{1}{2}$ years. Only a few cells were found in the latter at this age, but by the 3rd year the epididymides of all healthy males were packed with spermatozoa. There was no significant difference in testis tubule diameter per month $(P>0 \cdot 05)$. Testis weight showed an apparent seasonal fluctuation $(0.05>P>0.025)$, the lowest weight being recorded in the driest month, July, but the monthly sample was small (Table 3 ).

\section{THE FEMALE}

General description of the adult reproductive organs

The female reproductive tract was similar to that of the ewe and had a mean weight of $230 \mathrm{~g}(\mathrm{n}=7)$ in non-pregnant animals. The overall length from vulva to the curve of the cornua was about $30 \mathrm{~cm}$ and the vagina measured about $14 \mathrm{~cm}$ in length. The ovaries had smooth surfaces interrupted by the reddish swelling of the corpus luteum when present, and the smaller vesiclelike swellings of the follicles. The mean weight of the left ovary, $2.81 \mathrm{~g}$, was significantly greater than that of the right, $2.36 \mathrm{~g}(\mathrm{n}=80 ; 0.05>P>0.025)$. Mean dimensions of the left ovary were $21 \times 17 \times 13 \mathrm{~mm}$, and those of the right $21 \times 15 \times 11 \mathrm{~mm}$.

\section{Development of the ovary to puberty}

The ovaries of a 51-day ante partum foetus were small in size and consisted of germinal cells and connective tissue. Those of an 18-day ante partum specimen showed hypertrophy due to the development of Graafian follicles (Pl. 1, Fig. 1), weighed $0.50 \mathrm{~g}$ and $0.49 \mathrm{~g}$, and measured $10 \times 9 \times 9 \mathrm{~mm}$ each. Regression appeared to occur after birth. A female approximately 5 months old (weighing $43.6 \mathrm{~kg}$ ) had ovaries weighing $0.26 \mathrm{~g}(\mathrm{~L})$ and $0.21 \mathrm{~g}(\mathrm{R})$; they also contained Graafian follicles but apparently had a greater amount of connective tissue (Pl. 1, Fig. 2). A female of about 6 months, weighing $51.7 \mathrm{~kg}$, had ovaries of $0.60 \mathrm{~g}(\mathrm{~L})$ and $0.35 \mathrm{~g}(\mathrm{R})$, with much larger follicles reaching $4 \mathrm{~mm}$ in diameter. No animals less than 1 year old $(n=9)$ showed signs of corpora albicantia, and they were present in only two out of twelve animals aged 1 to 2 years.

In the 1st year of life, the mean paired ovary weight was $1.02 \mathrm{~g}$ and rose to $2.3 \mathrm{~g}$ in the 2 nd year; pregnant animals in their 2 nd year had ovaries exceeding $3 \mathrm{~g}$. By the $3 \mathrm{rd}$ year, mean adult ovary weight was reached.

\section{The mature ovary}

The follicle. Follicular development appeared to remain constant throughout life, the mean number of follicles per ovary being twenty-six (Table 4). Textfig. 1 shows that the follicles were probably also produced at a constant rate throughout most of the period of gestation, the apparent rise at parturition not being significant $(P>0.05)$. The number of follicles exceeding $5 \mathrm{~mm}$ in diameter, which averaged 1.4 per pair of ovaries, showed a rise at the beginning of pregnancy followed by a steady decline to nil at full term, and developed again in the post partum period (Table 5). The largest Graafian follicle measured $11 \mathrm{~mm}$ in diameter. 
PLATE 1
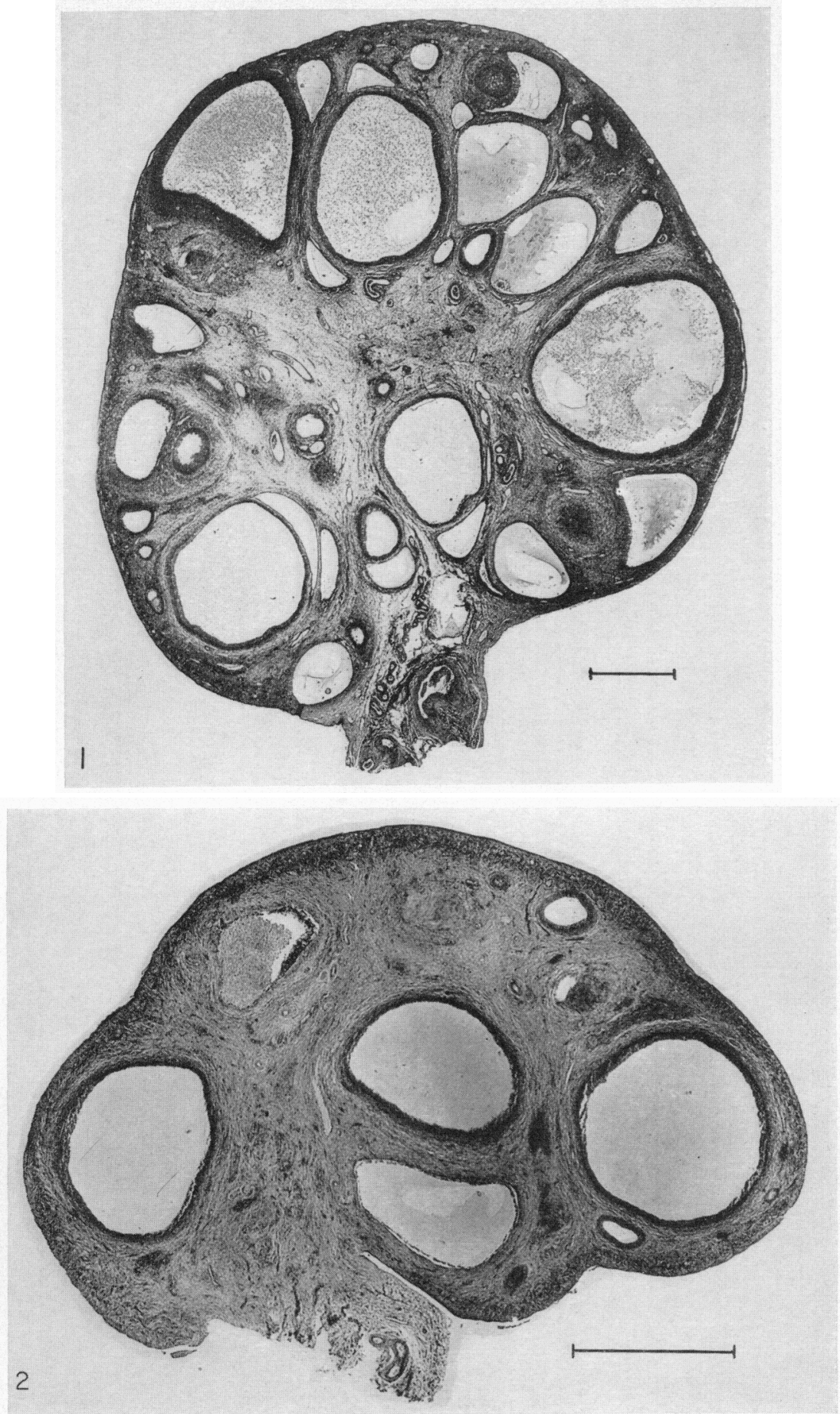

FiG. 1. Section of ovary of 222-day-old foctus showing Graafian follicles. Scale equals $1 \mathrm{~mm}$.

Fig. 2. Section of ovary of approximatcly j-month-old female showing an apparent reduction in ovary size and number of follicles. Scale equals $1 \mathrm{~mm}$. 
The corpus luteum. When the ovum was in the two-cell stage the corpus luteum was $6 \mathrm{~mm}$ in diameter and had attained $10 \mathrm{~mm}$ by the time that the four- to eight-cell stage was reached, with rapid occlusion of the lumen. The corpus luteum of pregnancy was maximum in size by the 30th day and remained constant in size until full term. After parturition regression occurred rapidly. No accessory corpora lutea were found.

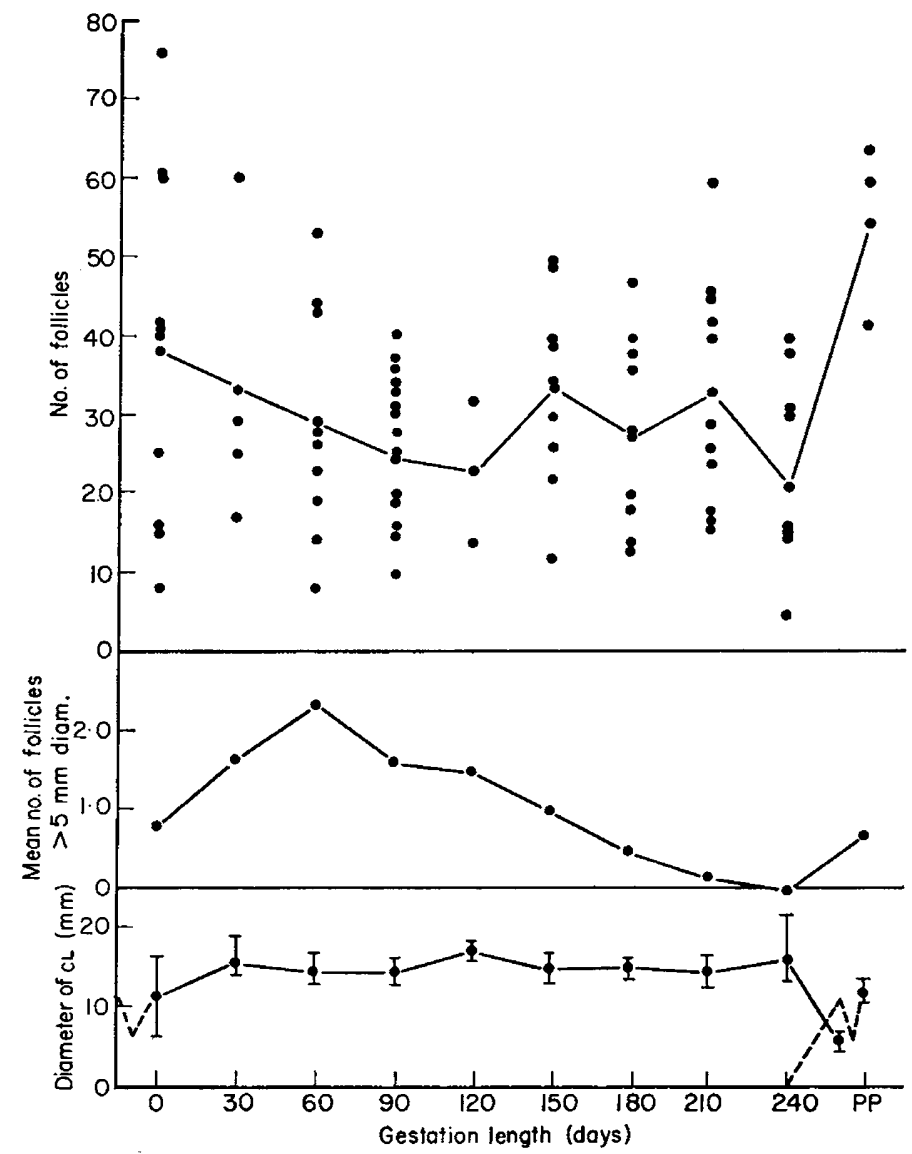

TEXT-FIG. 1. Ovarian changes during pregnancy. Top: Scatter diagram of number of follicles per pair of ovaries. Centre: Mean number of follicles $>5 \mathrm{~mm}$ diameter. Bottom: Mean diameter of the corpus luteum, vertical lines represent range. The broken line suggests the behaviour of the Graafian follicle at ovulation showing collapse in size after the ovum is extruded. The size of the corpus albicans is shown at 21 days post partum.

Sections of ninety-nine corpora lutea were examined histologically. Theca lutein cells could not be distinguished. The cytoplasm of the luteal cells appeared to undergo an increase in vacuolation towards full term but it was not readily apparent. Some luteal cells were darkly staining with dark nuclei having the appearance of pyknosis.

Corpora albicantia counts varied from nought in a 9-year-old animal to ten 
in a 10-year-old. There was no correlation between the number of observed corpora albicantia and the expected number of pregnancies (Table 6).

Gounts of corpora lutea plus corpora albicantia per ovary showed that the left ovary was 1.2 times more active than the right.

\section{TABLE 4}

MEAN NUMBER OF FOLLICLES VISIBLE TO THE NAKED EYE PER PAIR OF OVARIES FOR EACH YEAR OF AGE

\begin{tabular}{c|c|c|c}
\hline $\begin{array}{c}\text { Age } \\
\text { (years) }\end{array}$ & $\begin{array}{c}\text { Sample } \\
\text { size }\end{array}$ & $\begin{array}{c}\text { Mean no. of } \\
\text { follicles }\end{array}$ & $\begin{array}{c}\text { Range in no. } \\
\text { of follicles }\end{array}$ \\
\hline 1 & 9 & 26 & 16 to 41 \\
2 & 12 & 26 & 10 to 48 \\
3 & 2 & 26 & 13 to 39 \\
4 & 6 & 35 & 15 to 76 \\
5 & 8 & 27 & 13 to 45 \\
6 & 4 & 26 & 14 to 38 \\
7 & 9 & 23 & 12 to 43 \\
8 & 2 & 22 & 5 to 38 \\
9 & 6 & 29 & 19 to 42 \\
10 & 8 & 27 & 13 to 46 \\
11 & 3 & 31 & 8 to 50 \\
12 & 5 & 19 & 8 to 28 \\
13 & 1 & $>35$ & 13 to 54 \\
14 & 7 & 25 & 12 to 45 \\
\hline
\end{tabular}

TABLE 5

DEVELOPMENT OF THE GORPUS LUTEUM AND NUMBER OF FOLLIGLES > 5 MM IN DIAMETER DURING GESTATION

\begin{tabular}{c|c|c|c|c}
\hline $\begin{array}{c}\text { Days of } \\
\text { pregnancy }\end{array}$ & $\begin{array}{c}\text { Sample } \\
\text { size }\end{array}$ & $\begin{array}{c}\text { Mean no. } \\
\text { of follicles }\end{array}$ & $\begin{array}{c}\text { Mean diameter } \\
\text { of } C L(\mathrm{~mm})\end{array}$ & $\begin{array}{c}\text { Range of diameter } \\
\text { of } C L(\mathrm{~mm})\end{array}$ \\
\hline 0 & 10 & 0.8 & 11.4 & $6.0 *$ to 16.0 \\
0 to 30 & 6 & 1.6 & 15.6 & 14.0 to 19.0 \\
31 to 60 & 7 & 2.3 & 14.9 & 13.0 to 17.0 \\
61 to 90 & 16 & 1.6 & 14.8 & 13.0 to 16.0 \\
91 to 120 & 2 & 1.5 & 17.2 & 16.0 to 18.5 \\
121 to 150 & 10 & 1.0 & 15.1 & 13.0 to 17.0 \\
151 to 180 & 8 & 0.5 & 15.2 & 13.5 to 16.5 \\
181 to 120 & 12 & 0.2 & 14.6 & 12.5 to 17.0 \\
211 to 240 & 8 & 0 & 16.6 & 13.5 to 22.0 \\
Post partum & 3 & 0.7 & 12.0 & 11.0 to 14.0 \\
\hline
\end{tabular}

* Recent ovulation, egg in two-cell stage.

\section{Duration of reproductive activity}

The average female life-span was estimated to be about 13 years (Spinage, unpublished data); one exceptional animal, calculated to be $18 \frac{1}{2}$ years old at death, gave birth 2 months before she died although the calf was lost within 2 weeks. 
TABLE 6

MEAN NUMBER OF GORPORA ALBICANTIA FOR EACH YEAR OF LIFE

\begin{tabular}{c|c|c|c}
\hline $\begin{array}{c}\text { Age } \\
\text { (years) }\end{array}$ & $\begin{array}{c}\text { No. of } \\
\text { animals }\end{array}$ & $\begin{array}{c}\text { Mean no. of } \\
\text { corpora albicantia }\end{array}$ & Range \\
\hline 1 & 9 & 0 & 0 \\
2 & 12 & $0 \cdot 4$ & 2 to 3 \\
3 & 3 & 0.7 & 0 to 2 \\
4 & 8 & $1 \cdot 5$ & 0 to 3 \\
5 & 9 & $2 \cdot 0$ & 0 to 6 \\
6 & 7 & 1.5 & 0 to 3 \\
7 & 11 & $2 \cdot 0$ & 0 to 4 \\
8 & 3 & $2 \cdot 0$ & 1 to 3 \\
9 & 6 & 3.0 & 0 to 5 \\
10 & 9 & $4 \cdot 0$ & 2 to 10 \\
11 & 4 & 2.5 & 1 to 4 \\
12 & 5 & 4.5 & 3 to 8 \\
13 & 1 & 4.0 & 1 to 6 \\
14 & 7 & 4.0 & 1 \\
\hline
\end{tabular}

\section{Post partum oestrus}

Two marked females were killed at 61 and 62 days post partum, respectively. The first, aged 10 years, was not pregnant and the ovaries contained a corpus luteum $11.5 \mathrm{~mm}$ in diameter. The corpus albicans of the previous ovulation was $6.5 \mathrm{~mm}$ in diameter and pale yellowish in colour.

The second animal was 12 years old and bore a foetus estimated to be 43 days old. The corpus luteum was $13.0 \mathrm{~mm}$ in diameter and eight corpora albicantia were counted.

Two animals in their first pregnancies, with foetuses aged 72 and 176 days, had no corpora albicantia. The evidence from the second animal suggested that conception could sometimes take place at the first post partum oestrus, and the evidence from the two primiparous females suggested that conception could take place at the first oestrus.

\section{Pregnancy}

Implantation. Of the forty-seven animals examined, implantation had taken place in the left uterine horn in four cases and in the right in forty-three, a preference for implantation in the right of $92 \%$.

Placentation is of the cotyledonary, syndesmochorial type. Cotyledons were well formed by the 43rd day. Their number varied from twenty to forty-eight.

Foetal development. In the male, dark-coloured papillae of the horn primordia appeared by the 67 th day. By the 111th day, vibrissae were present on the snout and eyelids and the testes were above the scrotum. Both sexes were fully hirsute by the 181st day. The eyes opened about the 190th day and in the final week preceding parturition the first incisors may have cut the gum.

Of the sixty foetuses older than 30 days which could be sexed, thirty were male and thirty female.

No twins were seen. In none of the animals was it possible to obtain an accurate record of gestation length.

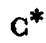




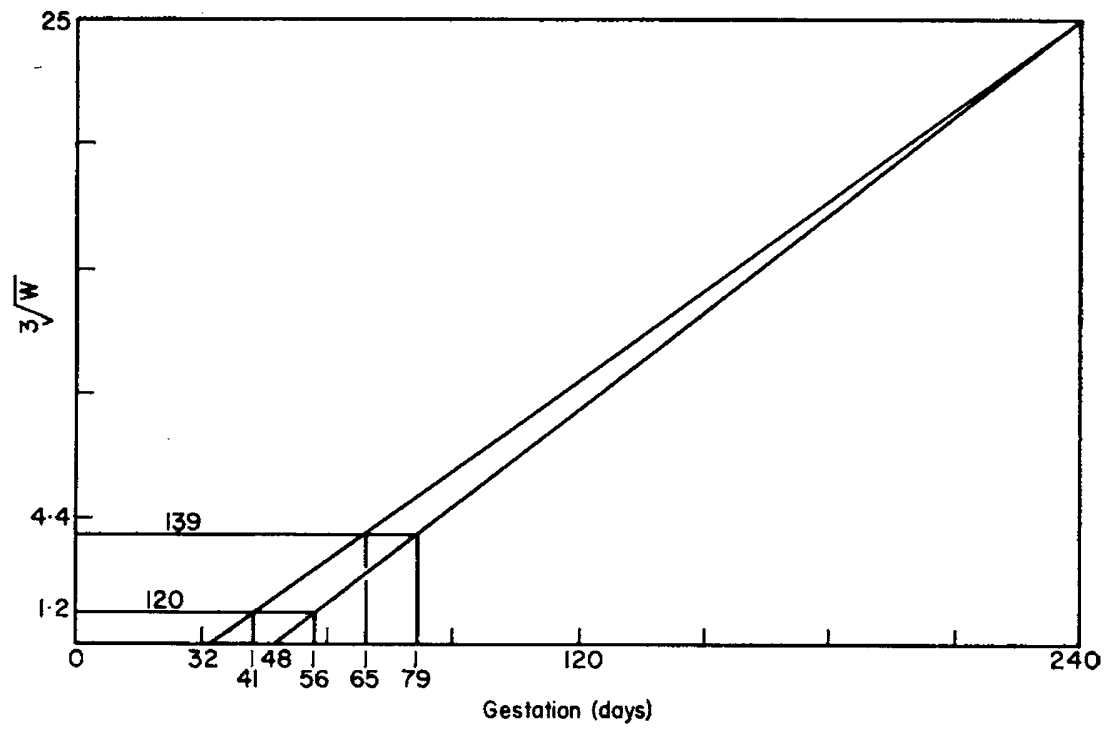

Text-Fic. 2. Method of determining a $t_{0}$ of 32 days using the formula of Huggett \& Widdas. See text for details.

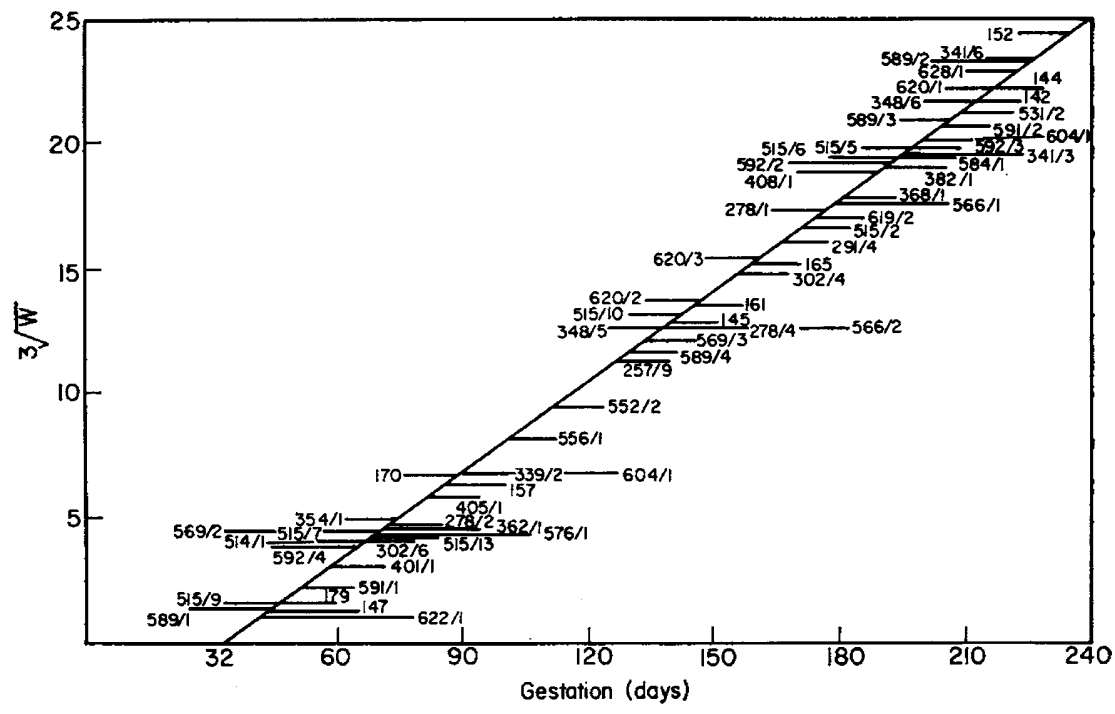

Text-FIG. 3. Distribution of weights of seventy-two foetuses against length of gestation using the formula of Huggett \& Widdas. 


\section{Birth prediction}

The date of birth of a foetus was predicted by using the method of Huggett \& Widdas (1951). Thirty-two days was chosen for the $x$ intercept for the following reasons. Female Y120 gave birth on 9th December 1966 and was killed on 9th February 1967, 62 days post partum, when the foetus weighed $1.87 \mathrm{~g}$ $(\sqrt[3]{\mathrm{W}}=1 \cdot 2)$. Y139 was killed 104 days post partum and had a foetus weighing $88.5 \mathrm{~g}(\sqrt[3]{\mathrm{W}}=4 \cdot 4)$. If $\sqrt[3]{\mathrm{W}}$ is plotted against days of gestation with a $t_{0}$ of 32 and 48 days, the maximum $\sqrt[3]{\bar{W}}$ being 25 at 240 days (the heaviest recorded foetus was $14.2 \mathrm{~kg}$ and gestation has been given as 240 days for $K$. ellipsiprymnus (Spector, 1956) and 243 days for $K$. defassa (Dekeyser, 1955), then the expected gestation period for known foetal weights can be predicted (Text-fig. 2).
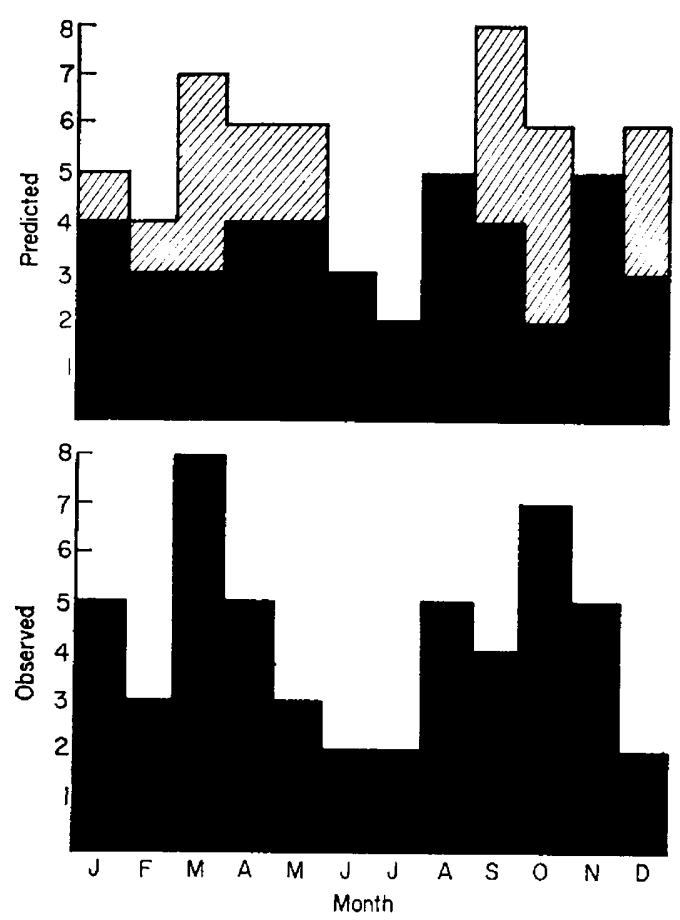

TEXT-FIG. 4. Distribution of births of waterbuck in the Queen Elizabeth Park predicted from foetal weights (top) and observed newborn calves (bottom). Cross-hatched sections in top diagram show births from animals collected in August and September which may bias the result.

The closest correlation is obtained with a $t_{0}$ of 32 assuming Y 139 passed 42 days post partum before conceiving again. This could have meant two oestrous cycles of 21 days, Heape (1901) giving a cycle length of 21 days for $K$. ellipsiprymnus.

Female Y120 gave birth on 16th April 1965, 11th February 1966 and 9th December 1966, giving two post partum intervals of 61 days. Y112 calved on 7th March 1966 and had calved again by 15th January 1967. She was killed on 6th March 1967, which should have been 65 days post partum; she was still not pregnant, although she had recently ovulated and had a regressing corpus albicans. 
The dates of birth of seventy-two foetuses were predicted (Text-fig. 3). Of these, nine were from the Semliki River Valley and have been omitted from subsequent analyses. Of the remaining sixty-three (three of which were neonates), $43 \%$ were collected in August and September in connection with other studies. The sample was, therefore, biased for the months of August to April

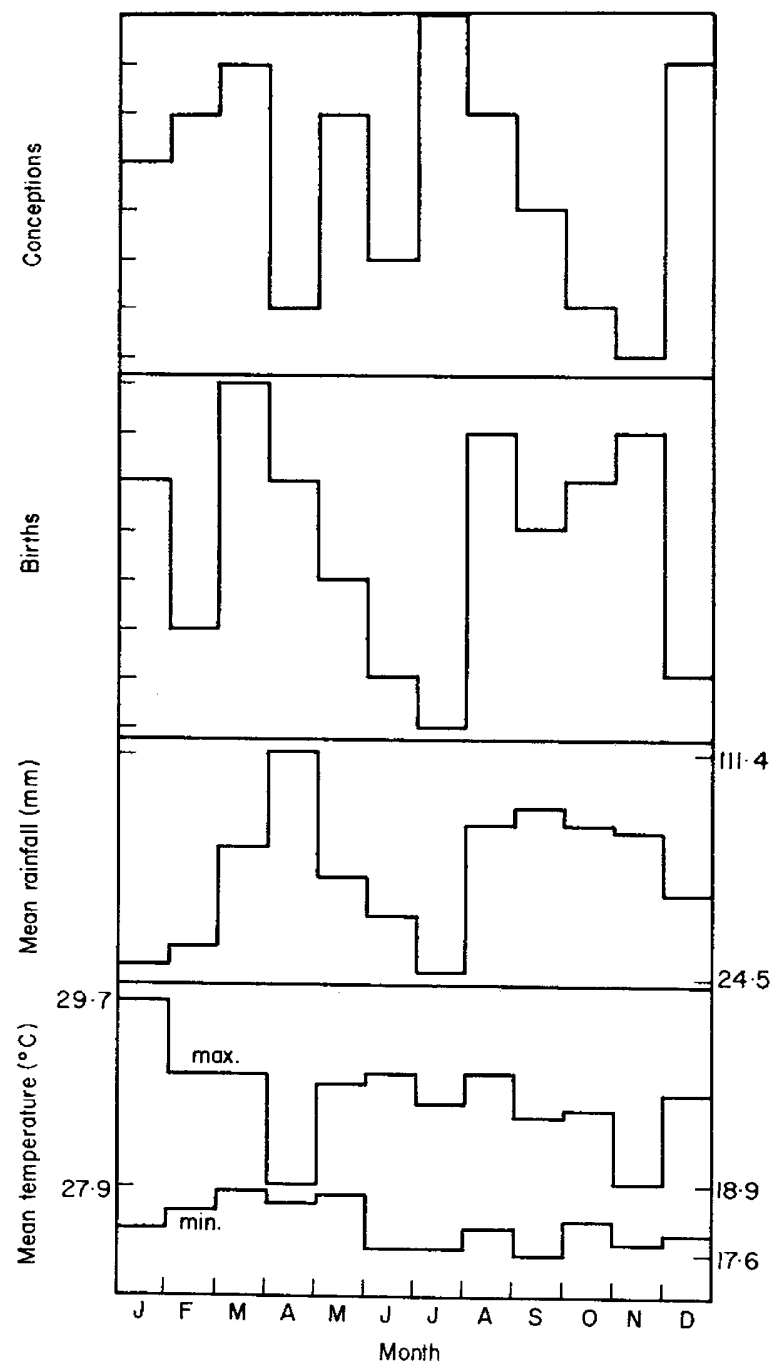

Text-FIG. 5. Correlation of seasonal distribution of births and conceptions with mean rainfall, mean minimum and mean maximum temperature.

against May to July. The total number of predicted births showed that parturition occurred throughout the year, but with two peaks correlated with the two wet seasons and a marked decline in the June-July dry season (Text-fig. 4). Assuming an equal chance of being born in any month of the year, this distribution was significant $(0.05>P>0.025)$. If the bias is removed $(n=63$ to 21$)$ 
then the distribution is no longer significant. Fifty-one, observed newborn calves showed a similar pattern with a significant decline during the dry seasons. Adding the 'unbiased' figures to the observed births showed a highly significant decline $(P<0 \cdot 001)$.

The latter data were converted to time of conception. Conceptions were then plotted against the 10-year average monthly rainfall for Mweya, and against mean monthly minimum and maximum temperatures recorded from 1965 to 1966. The closest correlation was found with the drop in maximum temperature, least conceptions occurring when the mean maximum temperature failed to rise above $27.9^{\circ} \mathrm{C}$ (April and November, see Text-fig. 5).

\section{The mammary gland}

The female has two pairs of inguinal teats. The mammary gland weighed approximately $40 \mathrm{~g}$ in the adult virgin female and reached a weight of nearly $2 \mathrm{~kg}$ when full of milk. Colostrum was produced at least 23 days before estimated parturition and was a thick, sticky yellowish liquid in the unsuckled gland. Regressed glands due to calf loss were common but no case of mastitis was observed $(n=24)$.

The quiescent gland consisted of much connective tissue and fat cells. Lactating glands had distended alveoli and secreting acini with a single-layered epithelium. The examination of histological sections could only reveal whether a gland recorded in the field as not lactating was in fact active. If lactating tissue was not found in section then it was not possible to say whether the animal was lactating without having examined most of the gland.

In a continually breeding animal like the waterbuck the adult should be permanently lactating except when she stops feeding the calf at heel to produce colostrum for the next birth.

\section{DISCUSSION}

\section{Pregnancy}

An asymmetrical preference for implantation is probably not unusual in wild ungulates. It has been recorded in the dikdik, Rhynchotragus kirkii (Kellas, 1954), Uganda kob, Adenota kob (Buechner, 1961) and impala, Aepyceros melampus (Mossman \& Mossman, 1962).

Statements such as "Twins perhaps not infrequent" (Ansell, 1960) are probably due to the fact that calves often associate so that two may be seen following one female. Riney \& Kettlitz (1964) record an instance of twins in $K$. ellipsiprymnus, whilst an oft-quoted reference is that of Frechkop (1954) who found three embryos in a female, a rare departure from normal as the waterbuck is undoubtedly monotocous.

\section{Sexual periodicity}

Although it has long been known that some African ungulates appear to breed throughout the year whilst others are more seasonal, there is little information to date upon sexual periodicity. Small reliance can be placed upon sub- 
jective estimates of calving periods as movement of observers in many parts of Africa is restricted during the wet seasons, giving bias to observations.

Laws \& Clough (1966) found in the hippopotamus, Hippopotamus amphibius, taken from the same area as the waterbuck, that peaks in numbers of births were correlated with peaks in rainfall, the distribution being similar to that of the waterbuck. In both species gestation length is the same; peaks in numbers of births occur in similar months and least numbers occur in June and July. The least numbers of conceptions also occur in October to November in both species, but the hippopotamus did not show a decline during April corresponding to that of the waterbuck.

As there are, on average, 5 dry months and 7 wet months in the year, the question first to be answered is whether, assuming an equal chance of conception or birth occurring in a wet or a dry month, the distribution of conceptions/ births is due to chance. Analysis shows that, for both species, the unequal distribution is significant $(0.05>P>0.025)$. Thus, in the waterbuck, $11 \%$ more conceptions in the dry seasons gives $22 \%$ more births in the wet seasons.

Testis weight appeared to show some cyclic fluctuation with minimal weights occurring in July, but there was no apparent correlation with rainfall fluctuations nor with fluctuations in numbers of conceptions. This may be due to the small sample size $(\mathrm{n}=38)$ for Clough (1966) found in the hippopotamus, using a sample size of 245 , that testis weight fluctuated randomly. But he found a correlation between testis activity, as measured by the relative numbers of different stages of spermatogenesis, and conceptions. In the waterbuck, the monthly sample was considered too small to justify such an analysis. As in the hippopotamus, there was no apparent correlation between testis tubule diameter and numbers of conceptions.

In relation to sexual periodicity, it can be assumed either that natural selection has operated to favour births at the most propitious time of the year, this being a teleological assumption in the absence of any knowledge of survival rates; or, that some environmental factor has a direct effect upon mating or conception. The former alternative is obviously inflexible for, if the seasons change, the young will be born at the wrong time.

In the waterbuck, there is as yet no evidence to suggest that dry seasons are unfavourable for calves. The numbers of conceptions were highest when the conditions were driest, and lowest just before the rainfall tailed off, or when the wet seasons were having their maximum effect. Amount or quality of food as a factor influencing conception is therefore a debatable question.

Photoperiodism, an important factor in sexual rhythms in temperate zones, is unlikely to constitute a factor as day length on the equator is constant to $\pm 2 \mathrm{~min}$ throughout the year. Times of sunrise and sunset vary $30 \mathrm{~min}$ between February and the end of October but show no obvious correlation with the numbers of births or numbers of conceptions.

The difference between minimum and maximum mean temperatures at Mweya ranged from $5 \cdot 0$ to $12 \cdot 1^{\circ} \mathrm{C}$. During the months when conception in the waterbuck was lowest, the maximum temperature failed to rise above $21.2^{\circ} \mathrm{C}$ on some days, whilst the minimum temperature dropped to $16^{\circ} \mathrm{C}$. Although these temperatures are within the accommodation range of waterbuck (Taylor 
\& Spinage, unpublished data), the fluctuation to which they are exposed is much more marked than is indicated by minimum and maximum mean temperature records. Whether temperature is a factor influencing sexual periodicity in the waterbuck is at present open to question, but the study of temperature as a causative factor in tropical sexual rhythms would seem to warrant more investigation than it has so far received.

\section{ACKNOWLEDGMENTS}

I am grateful to Dr R. M. Laws for his advice and encouragement in this project and to the Nuffield Unit of Tropical Animal Ecology for providing facilities. I am also grateful to the Director and Trustees of the Uganda National Parks for permitting this work to be carried out in the Queen Elizabeth Park, and to the Science Research Council of Great Britain who financed the project. I also wish to thank Miss B. O. Vidler who kindly cut most of the histological sections. Finally I am grateful to the Zoological Society of London for providing facilities at the Wellcome Institute of Comparative Physiology.

\section{REFERENCES}

Amoroso, E. G., Kellas, L. M. \& Harrison MatThews, L. (1954) The foetal membranes of an African waterbuck Kobus defassa. Proc. zool. Soc. Lond. 123, 477.

Ansell, W. F. H. (1960) Mammals of Northern Rhodesia. Government Printer, Lusaka.

Buechner, H. K. (1961) Unilateral implantation in the Uganda kob. Nature, Lond. 190, 738.

Clough, G. (1966) Reproduction in the hippopotamus. Ph.D. thesis, Cambridge.

DekeYser, P-L. (1955) Les mammiferes de l'Afrique Noire Francais. Vol. 1. 2nd edn. IFAN, Dakar.

Frechrop, S. (1954) Exploration du Parc National de l'Upemba. Vol. 14. Mammifères. Institut des Parcs Nationaux du Congo Belge.

Gerhardt, U. (1933) Kloake und Begattungsorgane. In: Handb. vergl. Anat. Wirbeltiere, Bd 5. Eds. L. Bolk, E. Göppert, E. Kallius and W. Lubosch. Berlin.

HEAPE, W. (1901) The sexual season of mammals and the relation of pro-oestrum to menstruation. Q. $7 l$ microsc. Sci. $\mathbf{4 4}, 1$.

Huggett, A. St. G. \& Widdas, W. F. (1951) The relationship between mammalian foetal weight and conception age. F. Physiol., Lond. 114, 306.

KELLAs, L. (1954) Observations on the reproductive activities, measurements, and growth rate of the dikdik (Rhynchotragus kirkii thomasi Neumann). Proc. zool. Soc. Lond. 124, 751.

Kiley-Worthington, M. (1965) The waterbuck (Kobus defassa Rüppell 1835 and $K$. ellipsiprymnus Ogilby 1833) in East Africa. Mammalia, 29, 177.

Laws, R. M. \& Glovgh, G. (1966) Observations on reproduction in the hippopotamus Hippopotamus amphibius Linnaeus. Symp. zool. Soc. Lond. 15, 117.

Mossman, A. S. \& Mossman, H. W. (1962) Ovulation, implantation and sex ratio in impala. Science, N.Y. 137, 869.

Riney, T. \& Ketturtz, W. L. (1964) Management of large mammals in the Transvaal. Mammalia, $28,189$.

Short, R. V. \& Spinage, C. A. (1967) Drug immobilisation of the defassa waterbuck. Vet. Rec. 79, 336.

SPECTOR, W. S. (1956) Handbook of biological data. Saunders, Philadelphia.

Spinage, C. A. (1967) Ageing the Uganda defassa waterbuck Kobus defassa ugandae. E. Afr. Wildl. $\mathcal{F}$. $5,1$.

SpINAGE, C. A. (1968) Naturalistic observations on the reproductive and maternal behaviour of the Uganda defassa waterbuck Kobus defassa ugandae Neumann. Z. Tierpsychol. (In press). 